\title{
How Effective Physical Exercise is for Improving Fertility in Obese Women With PCOS?
}

\author{
Dalia Ibrahim and Ahmed Nofal* \\ Department of Obstetrics and Gynecology, Menoufia University, Egypt
}

Submission: December 14, 2019; Published: January 03, 2020

*Corresponding author: Ahmed Mohammed Nofal, Department of Obstetrics and Gynecology, Menoufia University, Egypt

\begin{abstract}
Obese women with PCOS reduced conception rates compared weight-matched control subject. Insulin resistance and increased amount of visceral fat may be important mechanisms for reduced fertility in these women. Exercise training evidence have the benefits of glycaemic control and other metabolic disorder. Evidence have demonstrated different benefits in obese women PCOS who practice physical exercise like reduced the weight, insulin resistance, dyslipidaemia and fertility. Any way the articles published are insufficient until now to understand about the correlation among physical exercise, obese women with PCOS and fertility, we need to collect other knowledge
\end{abstract}

Keywords: Fertility; PCOS; Physical exercise; Aerobic exercise; Resistance exercise

\section{Fertility, Obese and Polycistic Ovary Syndrome}

$30 \%$ of female infertility are anovulation and physical exercise are known to be important like lifestyle factor; the relationship between exercise and ovulation is multi factorial and complex, and up till now the evidence are not clarified this aspect and also some specific guidelines about the type and intensity of exercise that the specialist doctor could be followed. Obesity is a known risk factor for ovulation problems, but it also contributes to infertility in women who ovulate normally. Overweight and obese women have higher levels of a hormone called leptin, which is produced in fatty tissue. This can disrupt the hormone balance and lead to reduced fertility.

Polycystic ovary syndrome (PCOS) is a prevalent and heterogeneous condition affecting $6-20 \%$ of reproductive-aged women and $35-40 \%$ of infertile women [1-2]. PCOS is the most common cause of chronic anovulation [3]. Women with PCOS could be suffer of different varying degree of insulin resistance, correlated with body weight if compare to weight-matched controls subject. Long term the women with PCOS increased the possibilities to develop metabolic dyslipidemia.
Effect of Aerobic and Resistance Training Metabolic Value

Several studies has showed like different level of intensity and type of exercise produce different effect on glycemic control, above all combined aerobic and resistance training have been demonstrated most beneficial [4] In general population, high intensity interval training has shown to be more effective in regulating glucose than continuous training at lower intensity [5]. Peak oxygen consumption (peakV02), gold standard measurement of Fitness, may also be improved [6] as well as glycemic control [7] in individuals with type II diabetes who practice regular aerobic exercise.

The evidence has undelighted like resistance training intervention reduce systolic blood pressure in patients with METs, but not fasting plasma glucose, HDL cholesterol, triglycerides, diastolic blood pressure, or waist circumference [8]. Anyway different studies suggest moderate exercise to high intensity exercise and the reason are: the stimulus from exercise at any intensity is considered sufficient to exert clinical improvements; 
intuitively one may consider lower intensity exercise training mitigates the likelihood of exercise related medical events; low to moderate intensity exercise can be performed by most people [7].

\section{Effect Exercise in PCOS Patients E Fertility}

Analyses of lifestyle interventions are yet to show a reduction in the proportion of participants who meet the diagnostic criteria for MetS [9], although summary data are available outlining significant improvements in both body composition and metabolic profile measures with lifestyle intervention in women with metabolic derangement due to polycystic ovarian syndrome [10]. Lifestyle (diet and exercise) has been shown to be effective in resolving MetS and reducing the severity of related abnormalities (fasting blood glucose, waist circumference, systolic blood pressure and diastolic blood pressure, and triglycerides) [11].

A Danish prospective cohort study [12] found a strong relation between vigorous PS and fecundity relative by BMI. Vigorous PA was associated with reduced fecundability among lean women $\left(\mathrm{BMI}<25 \mathrm{~kg} / \mathrm{m}^{2}\right)$, and increased fecundability in overweight/ obese women (BMI $>25 \mathrm{~kg} / \mathrm{m}^{2}$ ) while moderate PA was associated with a small increase in fecundability. Harrison et al. [13], in their relevant study, demonstrated that exercise was effective in restoring fertility even when there was no associated weight loss.

An interest study [14] observed that the weight loss, including exercise advice and diet intervention , on obese women undergoing assisted fertilization, after 12 week increased pregnancy rates. This data is also supported by Palomba et al who concluded in their study that regular physical acitiviti is assocviated with improved fertility in obese women going through fresh in vitro fertilization (IVF. (15).

Finally an interesting study, in which was enrolled women with PCOS, HOMS-IR and insulin improved after the 8 week of moderate intensity exercise and it was demonstrated that insulin stimulated glucose disposal in skeletal muscle reached similar value like group control [16]. PCOS patients showed more tolerant of lipid induce IR after exercise and became comparable with control to prior to exercise, even if it was not reversed to that level seen for normal controls following exercise.

\section{Conclusion}

Lifestyle interventions, including regular exercise, healthful diet, and weight loss, are recommended to improve fertility in overweight and obese women, especially with PCOS, and It would be considered for this reason to be insert in traditional no pharmacological intervention in this type of patients. Until now the evidence has demonstrated that physical exercise, not improved only the level of fertility but also other important health problem, like insulin resistance. We need more knowledge about the underlying mechanisms for improvements in fertility after a period of exercise training in PCOS if we want to have, like another type of patients, some specific guidelines that could be help to prescribe physical exercise.

\section{References}

1. Knochenhauer ES, Key TJ, Kahsar-Miller M, Waggoner W, Boots LR, et al. (1998) Prevalence of polycystic ovary syndrome in unselected black and white women of the southeastern United States: a prospective study. J CLin Endocrinol Metab 83(9): 3078-3082.

2. Frank S (1995) Polycysticovary syndrome. N Engl J Med 333(13): 853861.

3. Frank S, Adam J, Mason H (1985) Ovulatory disroders in women with plycistic ovarian syndrome. Clin Obstet Gynecol 12(3): 605-632.

4. Schwingshackl L, Missbach B, Dias S, König J, Hoffmann G, et al. (2014) Impact of different training modalities on glycaemic control and blood lipids in patients with type 2 diabetes: a systematic review and network meta-analysis. Diabetologia 57(9): 1789-1797.

5. Jelleyman C, Yates T, O’Donovan G, Gray LJ, King JA, et al. (2015) The effects of high-intensity interval training on glucose regulation and insulin resistance: a meta-analysis. Obes Rev 16(11): 942-961.

6. Boule NG, Kenny GP, Haddad E, Wells GA, Sigal RJ, et al. (2003) Metaanalysis of the effect of structured exercise training on cardiorespiratory fitness in Type 2 diabetes mellitus. Diabetologia 46(8): 1071-1081.

7. Snowling NJ, Hopkins WG (2006) Effects of different modes of exercise training on glucose control and risk factors for complications in type 2 diabetic patients: a meta-analysis. Diabetes Care 29(11): 2518-2527.

8. Lemes IR, Ferreira PH, Linares SN, Machado AF, Pastre CM, et al. (2016) Resistance training reduces systolic blood pressure in metabolic syndrome: a systematic review and meta-analysis of randomised controlled trials. Br J Sports Med 50(23):1438-1442.

9. Yamaoka K, Tango $T$ (2012) Effects of lifestyle modification on metabolic syndrome: a systematic review and metaanalysis. BMC Med 10: 138 .

10. Haqq L, McFarlane J, Dieberg G, Smart N (2014) Effect of lifestyle intervention on the reproductive endocrine profile in women with polycystic ovarian syndrome: a systematic review and meta-analysis. Endocrine connections 3(1): 36-46.

11. Wise LA, RothmanKJ, Mikkelsen EM, Sorensen HT, Riis AH, et al. (2012) A prospective cohort study of physical acitivity and time to pregnancy. Fertil Steril 97(5): 1136-1142.

12. Harrison CL, Lombard CB, Moran LJ, Teede HJ (2011) Exercise therapy in polycystic ovary syndrome: a systematic review. Hum Reprod Update 17(2): 171-183.

13. Sim KA, Dezarnaulds GM, Denyer GS, Skilton MR, Caterson ID, et al (2014) Weight loss improves reproductive outcomes in obese women undergoing fertility treatment: a randomized controlled trial. Clinical Obesity 4(2): 61-68.

14. Palomba S, Falbo A, Valli B, Morini D, Villani MT, et al. (2014) Physical activity before IVF and ICSI cycles in infertile obese women: an observational cohort study. Reprod Biomed Online 29(1): 72-79.

15. Bird SR, Hawley JA (2017) Update onthe effects of physical activity on insulin sensitivity in humans. BMJ Open Sport EXerc Med 2(1):e000143.

16. Randeva HS, Tan BK (2012) Cardiometabolic Aspect of the Plycystic Ovary Syndrome. Endocr Rev 33(5): 812-841. 
CC (P) This work is licensed under Creative
Your next submission with Juniper Publishers will reach you the below assets

- Quality Editorial service

- Swift Peer Review

- Reprints availability

- E-prints Service

- Manuscript Podcast for convenient understanding

- Global attainment for your research

- Manuscript accessibility in different formats

( Pdf, E-pub, Full Tsext, Audio)

- Unceasing customer service

Track the below URL for one-step submission https://juniperpublishers.com/online-submission.php 